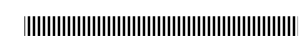

Original Paper

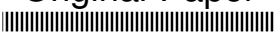

\title{
Evaluation of Visual Comfort for Wallpaper by Image Analysis
}

\author{
KAWAMOTO Naoki \\ Department of Home Economics, Kyoto Bunkyo Junior College, 80 Senzoku, Makishima, Uji, Kyoto, 611-0041 Japan
}

Received 13 June 2003; accepted for publication 6 September 2004

\begin{abstract}
The purpose of this study is to evaluate visual comfort of wallpaper by using image analysis. First of all, 30 human observers estimated the visual comfort for various samples of wallpaper on a CRT display. Next, we examined the relationship between the visual comfort estimated by the human observers and each of 4 feature parameters obtained by image analysis, that is, average lightness, average chromaticness, average spatial frequency, and entropy in spatial frequency domain. Clearly, the visual comfort of wallpaper has a good positive correlation with the average lightness, and a good negative correlation with the average chromaticness. Furthermore, a multiple regression analysis was performed by using these feature parameters to predict the visual comfort. The regression equation included 6 explanatory variables, that is, the 4 feature parameters and the second order terms of average spatial frequency and entropy. The result showed that the regression coefficients were negative for the second order terms of the 2 feature parameters, therefore, wallpaper with medium values of average spatial frequency and entropy was evaluated as comfortable. In other words, this suggests that the wallpaper with medium coarseness(fineness) and moderate spatial periodicity tends to bring the visual comfort.
\end{abstract}

Key Words: Wallpaper; Visual comfort; Image analysis

\section{画像解析による壁紙の視覚的快適性評価}

\author{
河本 直樹
}

\section{1. まえがき}

室内の色彩環境等による視覚的快適性を考える上で, 壁紙は最も重要と思われる要素の一つである，壁紙には 種々の素材, 種々の色柄のものが存在するが, 本稿では 素材による効果については考えず，色柄による効果のみ を扱うものとする．すなわち種々の色柄を有する壁紙の ディジタル画像をサンプルとして用いる.

色による感情効果を定量化しようとする試みは, これ までにもいくつか報告されているが, それらはほとんど, 単色[1-3]あるいは 2〜3 色による単純な配色パターン [4-11]を用いた基礎研究であり, 壁紙等のように種々の柄 を含む実在パターンの評価に適用できるものではない. また, 柄のイメージや嗜好に関する研究報告もあるが, 例えば, ストライプ[12-14], チェック[15-16], 水玉[17-19] 等のように，いわゆる規則的なパターンを対象としたも
のがほとんどであり，一般の壁紙のように不規則なある いは複雑な柄を含む場合への適用は, やはり難しい. 河本[20]は, 正規乱数によるモザイクパターンを用いる ことによって, 複雑さや美しさ等の視覚的印象が, どの ような画像特徵量と関連付けられるかを検討しているが, 実在の柄やデザインへの応用については言及していない. そこで本研究では, 実在パターンの例として室内用壁紙 をとりあげ, その視覚的快適性の度合を, 壁紙がもつい くつかの画像特徵量から予測するための手法について検 討した.

\section{2. 方法}

\section{1 サンプル}

市販の住宅デザインソフト「3D マイホームデザイナ 


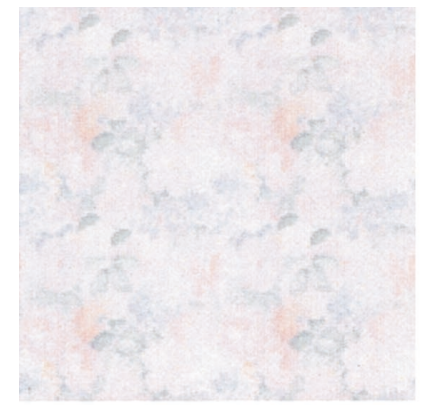

No.2

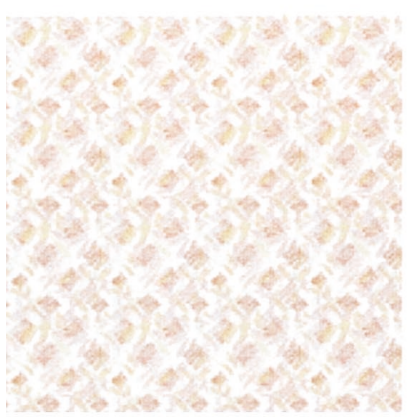

No.7

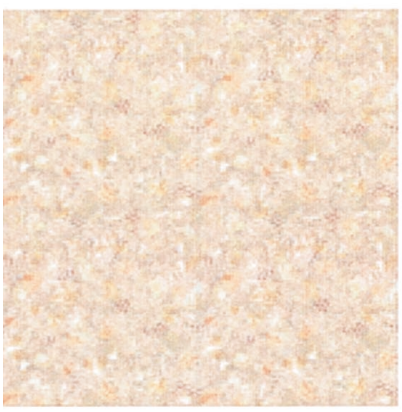

No.13

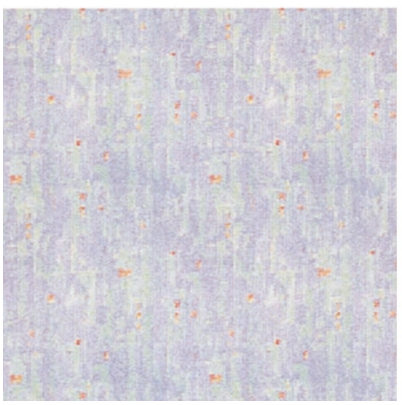

No.21

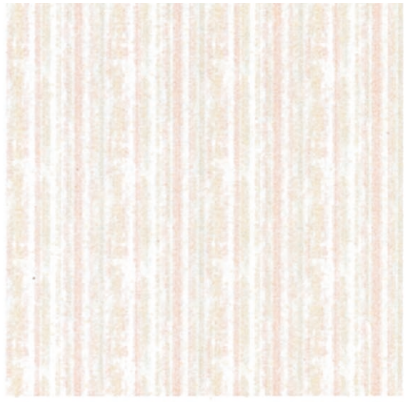

No.3

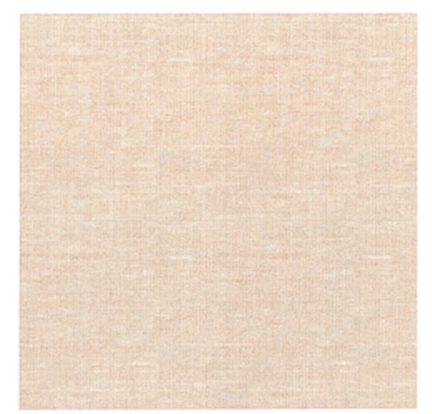

No.8

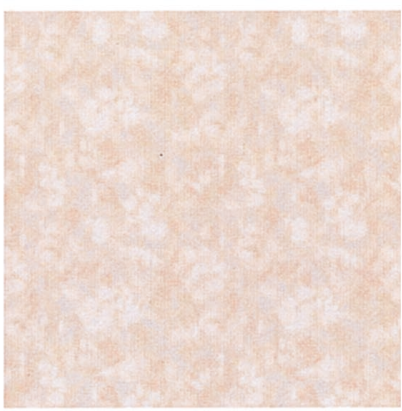

No.17

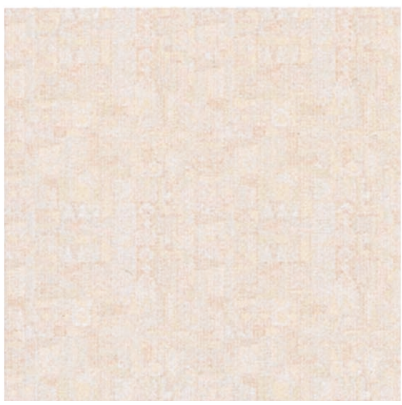

No.22

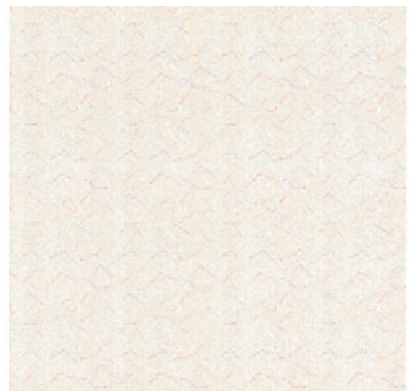

No.4

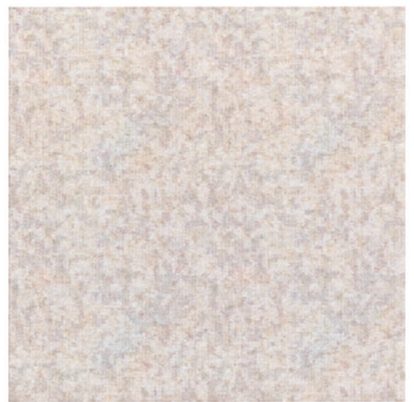

No.10

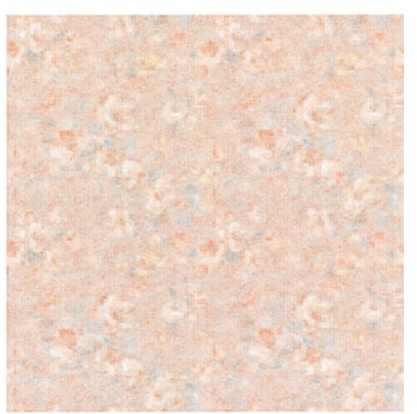

No.18

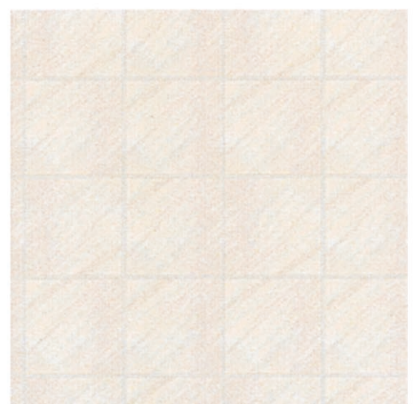

No.25

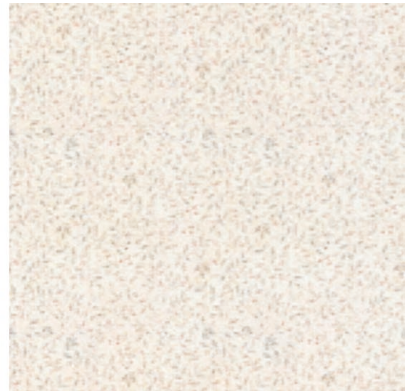

No.5

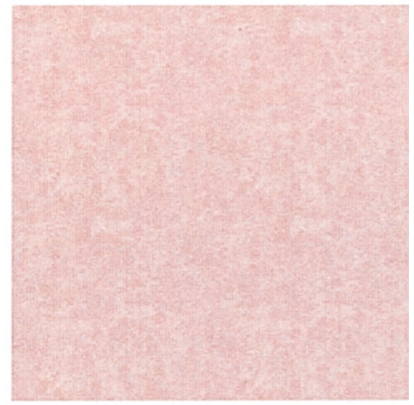

No.12

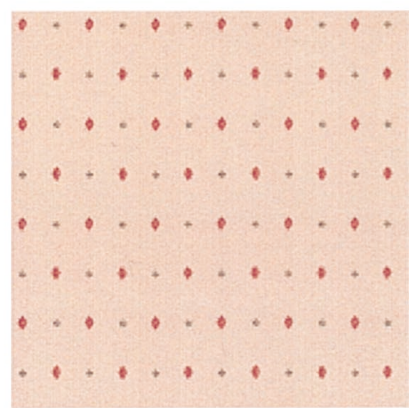

No.20

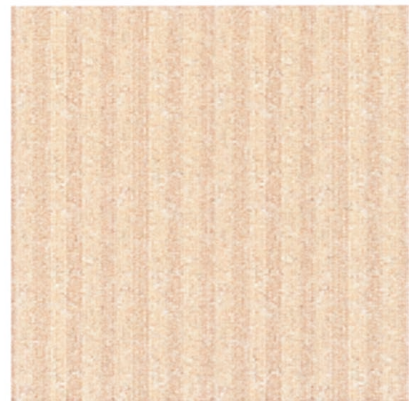

No.34

Fig.1 Example images of wallpaper. $(256 \times 256$ pixels $)$ 
一」（MEGASOFT）用のインテリア素材集 CD-ROM に収録さ れているすべての壁紙画像 34 点をサンプルとして用い た。これらの壁紙は室内用として実際に製造・販売され ているもの（東リ製）を上記ソフト用のディジタル画像 （BMP 形式）としたものである. 収録されている画像の サイズは $128 \times 128$ 画素であるが, 本研究ではリピート処 理により $512 \times 512$ 画素として用いた. サンプルの一部を 図 1 に示す.（図1ではサンプルの 4 分の 1 の領域に相当 する $256 \times 256$ 画素の部分を示している.)

柄の種類としては，草花をモチーフにしたやや具象的 なもの（図 1 の No.2，5，17，18 など）も $5 \sim 6$ 点ある が, その他は, 無地に近いもの (図 1 の No. 8, 12 など),

ストライプ状のもの (図 1 の No.3，34 など), 幾何学模 様のようなもの（図 1 の No.20，22 など）というような 抽象的なものがほとんどである. 具象柄においては，そ のモチーフ自体のもつ意味が快適性の主観評価に影響を 及ぼすことが考えられるが，上述のように，具象柄のサ ンプルはかなり少なく，しかもその中にはやや抽象化さ れていてモチーフ自体の印象がそれほど強くないものも 含まれているため, 本研究ではその影響については言及 しないものとする.

\section{2 視営的快適性の主筧的評価方法}

短期大学の家政学科に所属する $19 \sim 20$ 歳の女子学生 30 名による被験者が, 上記 34 点のサンプル画像を CRT モニタ上で観察しながら，その快適性を主観的に評価し た．本来，壁紙による快適性は，その壁紙が施された室 内に居て，評価されるべきものであるが，研究の簡便の ため,ここでは CRT モニタ上での観察による評価とした. 評価尺度については, 室内および屋外のシーンを撮影し た画像から受ける快適感を CRT 上で評価させた佐川 [21] の研究を参考に,「最も快適」と感じる場合を 10 ,「最も 不快」と感じる場合を 0 とする 11 段階とした. 室内用壁 紙には比較的よく似たものや無難なものも多いため, 評 価尺度を $5 \sim 7$ 段階程度とすると, 評価が中央に偏って しまったり，サンプル間の小さな差が反映されなかった りするのではないかと考え，11 段階のやや細かい尺度を 採用した.

評価に際して特別なインストラクションは与えず，た だ「室内の壁紙として快適と感じるかどうかを率直に評 価するように」との説明のみを行った．もちろん本研究 の目的や内容についても一切の情報を与えなかった.

サンプル画像のサイズは $512 \times 512$ 画素であり,これを $800 \times 600$ 画素の解像度に設定された 15 インチサイズの カラーCRT モニタ（イーヤマ製 S500M1）のほぼ中央に黒 色を背景として表示した．画像の実サイズは約 $18 \times 18 \mathrm{~cm}$ となり, 被験者はこれを約 $70 \mathrm{~cm}$ の視距離で観察したので, 視角に換算すれば約 $14^{\circ}$ となる.

サンプル画像の呈示時間は特に制限せず，観察および
評価を終えた時点で被験者自身がコンピュータのキーを 押すことにより（約 3 秒間, 何も表示されない黒色画面 の状態を経て）次のサンプルが呈示されるようにした. ほとんどの被験者が数秒 10 秒程度で 1 サンプルの評価 を終えた．またサンプルの呈示順序による影響を除くた め，呈示順序は被験者ごとにランダムに決めた．実験は 大学の研究室内（通常の白色蛍光灯による照明の下）で 行った. モニ夕近辺の照度は約 400 lx であった.

\section{3. 結果と考察}

\section{1 視觉的快適性の主観的評価結果}

まず全被験者 30 名の平均評価値を求めた後, その平均 評価值と各被験者による評価値との相関をそれぞれ調べ た結果, 危険率 $5 \%$ 以下で相関ありと認められる被験者 は 23 名であった. 逆にいえば, 平均とは異なるやや個性 的な評価をした被験者が 7 名いたことになる.この研究 では，とりあえず個人差の問題は扱わずに，快適性評価 の一般的な傾向を見るために，上記 7 名の評価デー夕を 除いた残り 23 名による平均評価値をあらためて算出し た.この 23 名の平均評価值および標準偏差を表 1 の左か ら 2 列目および 3 列目に示した. 平均評価値は, サンプ ル No.8の 5.96 が最高, サンプル No. 29 の 1.74 が最低と なっており，全般にやや低めだが，これは快適性評価が CRT 上の観察によって行われたことに起因するものでは ないかと推察している.いずれにせよ, 表 2 の分散分析 にもあるように, サンプル間の変動は被験者間の変動に 比べて十分に大きく, これら 23 名の平均評価値をこの後 の分析対象として使用することにする.

\section{2 壁紙画像の特徽量の抽出}

画像の視覚的印象を表現するための特徵量としては 様々なものが考えられるが，本研究では，これまでの研 究結果 $[20]$ などを参考にしながら, 以下のような特徵量 について抽出・検討するものとした.

- 平均明度

. 平均彩度

- 空間周波数の平均值（以下では平均周波数と記述）

・空間周波数領域におけるエントロピー

（以下では単にエントロピーと記述）

これらの他にも一般的な画像特徵量として, 例えば平 均色相が考えられるであろうし，また使用色間の色差の 大きさを表すような特徵量 (明度, 彩度, 色相に関する 標準偏差など）も考えられるが，今回のようにいわゆる 室内壁紙においては, 暖色系の平均色相をもつものが圧 
Table 1 Average values and standard deviations of visual comfort and 4 feature parameters obtained by image analysis.

\begin{tabular}{|c|c|c|c|c|c|c|}
\hline $\begin{array}{l}\text { Sample } \\
\text { no. }\end{array}$ & $\begin{array}{l}\text { Average values } \\
\text { of } \\
\text { visual comf or t }\end{array}$ & $\begin{array}{c}\text { Standard } \\
\text { deviations of } \\
\text { visual comf ort }\end{array}$ & $\begin{array}{l}\text { Average } \\
\text { lightness }\end{array}$ & $\begin{array}{c}\text { Average } \\
\text { chromaticness }\end{array}$ & $\begin{array}{l}\text { Average } \\
\text { spatial } \\
\text { frequency }\end{array}$ & $\begin{array}{c}\text { Entropy in } \\
\text { spatial frequency } \\
\text { domain }\end{array}$ \\
\hline 1 & 2.57 & 1.34 & 89.56 & 37.84 & 17.84 & 0.291 \\
\hline 2 & 4.30 & 1.96 & 94.77 & 2.22 & 11.93 & 0.394 \\
\hline 3 & 5.13 & 1.79 & 97.43 & 5.74 & 26.35 & 0.404 \\
\hline 4 & 4.48 & 2.04 & 97.14 & 7.60 & 35.92 & 0.558 \\
\hline 5 & 3.48 & 1.44 & 95.19 & 7.24 & 36.19 & 0.682 \\
\hline 6 & 4.57 & 2.02 & 98.48 & 2.23 & 17.18 & 0.364 \\
\hline 7 & 3.70 & 1.52 & 97.30 & 5.22 & 27.20 & 0.406 \\
\hline 8 & 5.96 & 1.87 & 91.46 & 10.27 & 20.29 & 0.522 \\
\hline 9 & 5.57 & 2.04 & 95.75 & 5.11 & 34.41 & 0.553 \\
\hline 10 & 3.30 & 1.55 & 89.32 & 4.27 & 23.58 & 0.581 \\
\hline 11 & 2.30 & 1.55 & 80.96 & 37.35 & 18.93 & 0.507 \\
\hline 12 & 4.26 & 2.18 & 91.50 & 10.14 & 25.29 & 0.584 \\
\hline 13 & 3.13 & 1.84 & 93.94 & 11.66 & 26.60 & 0.590 \\
\hline 14 & 5.48 & 1.70 & 95.14 & 3.51 & 31.64 & 0.523 \\
\hline 15 & 3.74 & 1.42 & 94.89 & 3.33 & 30.43 & 0.648 \\
\hline 16 & 4.26 & 1.84 & 90.68 & 8.67 & 27.05 & 0.423 \\
\hline 17 & 5.13 & 1.79 & 93.23 & 7.05 & 17.03 & 0.478 \\
\hline 18 & 3.70 & 2.01 & 92.13 & 10.15 & 22.93 & 0.571 \\
\hline 19 & 4.39 & 2.25 & 88.97 & 6.67 & 17.48 & 0.542 \\
\hline 20 & 3.65 & 1.80 & 92.06 & 13.05 & 29.57 & 0.452 \\
\hline 21 & 2.57 & 1.59 & 89.45 & 6.97 & 21.15 & 0.551 \\
\hline 22 & 4.96 & 1.52 & 94.34 & 7.14 & 24.19 & 0.584 \\
\hline 23 & 3.78 & 1.24 & 97.36 & 3.19 & 21.13 & 0.527 \\
\hline 24 & 5.83 & 1.83 & 96.69 & 1.90 & 16.11 & 0.464 \\
\hline 25 & 4.35 & 2.04 & 96.97 & 6.10 & 17.61 & 0.471 \\
\hline 26 & 3.09 & 1.93 & 89.96 & 9.09 & 10.14 & 0.393 \\
\hline 27 & 3.09 & 1.59 & 90.48 & 15.62 & 21.20 & 0.547 \\
\hline 28 & 2.70 & 1.29 & 82.70 & 19.77 & 32.71 & 0.618 \\
\hline 29 & 1.74 & 1.21 & 82.08 & 34.24 & 46.92 & 0.566 \\
\hline 30 & 1.91 & 1.24 & 76.61 & 33.00 & 34.99 & 0.559 \\
\hline 31 & 2.04 & 1.26 & 72.66 & 47.06 & 30.70 & 0.504 \\
\hline 32 & 3.04 & 1.52 & 86.06 & 25.91 & 25.57 & 0.441 \\
\hline 33 & 2.48 & 1.65 & 81.94 & 14.38 & 49.44 & 0.454 \\
\hline 34 & 3.78 & 1.59 & 91.25 & 14.48 & 28.84 & 0.320 \\
\hline
\end{tabular}

Table 2 Result of analysis of variance.

\begin{tabular}{|c|c|c|c|c|}
\hline $\begin{array}{c}\text { Cause of } \\
\text { variance }\end{array}$ & $\begin{array}{c}\text { Sum of } \\
\text { squares }\end{array}$ & $\begin{array}{c}\text { Degree of } \\
\text { freedom }\end{array}$ & $\begin{array}{c}\text { Mean } \\
\text { square }\end{array}$ & $\begin{array}{c}\text { F } \\
\text { value }\end{array}$ \\
\hline Samples & 1000.59 & 33 & 30.321 & 10.315 \\
\hline Subjects & 2198.69 & 748 & 2.939 & \\
\hline Total & 3199.28 & 781 & & \\
\hline
\end{tabular}

倒的に多いことや, 色差もほとんどの場合あまり大きく ないことなどの実際的状況を勘案して，上記 4 種類の特 徵量を用いることとした. 各特徵量を抽出するための具 体的な計算方法について以下に述べる.

まず壁紙画像の各画素の RGB 值を近似的にCIELAB 值に 変換し, $L^{*}, a^{*}, b^{*}$ 值による画像デー夕配列とする. 平均 明度は $L^{*}$ の平均值とし, 平均彩度については各画素の $a^{*}, b^{*}$ 值から $C^{*}=\left\{\left(a^{*}\right)^{2}+\left(b^{*}\right)^{2}\right\}^{1 / 2}$ を求め, その平均值を用 
いた.

一方, $L^{*}, a^{*}, b^{*}$ 画像デー夕配列にそれぞれ 2 次元フーリ 工変換を施し, パワースペクトル $P(u, v)$ を求める. 次 にそのパワースペクトルを極座標形式に変換し, 距離 $I$ についての成分和 $P(r)$ を用いる. $\left(r^{2}=u^{2}+v^{2}, u, v\right.$ はそ れぞれ水平方向, 垂直方向の周波数を示す.) さらに, 視 覚系の空間周波数応答特性を考慮するために, $P(r)$ に次 のような簡単なローパス型のフィルタをかける.

$$
h(r)=1 /\left\{1+\left(r / r_{0}\right)^{\alpha}\right\}
$$

視覚系の空間周波数応答特性に関しては種々の研究報 告 [22-26]があるが, 研究者や測定方法により若干の相違 も見られるため, 本研究ではそれらの結果をおおよその 参考としながら, 上記の関数を独自に設定した. 式 (1) から分かるように, $r=r_{0}$ のとき, $h\left(r_{0}\right)=1 / 2$ で, 利得が 半分になる. 使用した壁紙画像のサイズは $512 \times 512$ 画素 であり, 水平および垂直方向の空間周波数 $u, v$ の最大值 は 256，したがって $r$ の最大值は 362 となる.ここでは $I_{0}=160$ とした. 主観的評価の際, 被験者は視角約 $14^{\circ}$ で画像を観察したので， $r$ の值を 14 で割ることにより cycles/degree の単位に換算できる． $r_{0}=160$ は約 $11 \mathrm{cycles} /$ degree に相当する. また利得低下の傾きに寄 与する指数 $\alpha=4$ とした.

ここまでの処理は $L^{*}, a^{*}, b^{*}$ 各画像成分について行い, その後 3 成分のスペクトルを周波数ごとに加算したもの を $P_{\mathrm{Lab}}(r)$ とする. 視覚的快適性評価に際し， 3 成分のス ペクトルそれぞれに固有の寄与が存在することも考えら れるが，本研究では簡単のため，上述のような加算を行 い,一つのスペクトルにまとめた.この $P_{\mathrm{Lab}}(r)$ を用いて, 平均周波数 $r_{\text {average }}$ を次式 (2)により求める.

$$
I_{\text {average }}=\left\{\sum_{r} r \cdot P_{\text {Lab }}(r)\right\} / \sum_{r} P_{\text {Lab }}(r)
$$

平均周波数 $r_{\text {average }}$ の值は, 画像におけるパターンの粗密 の程度を表す.すなわち, 壁紙がもつ主要な（特徵的な） 柄が細かいほど, 大きい值となる.

また, $P_{\mathrm{Lab}}(r)$ を次式 (3)により正規化したものを $p(r)$ とする.

$$
p(r)=P_{\text {Lab }}(r) / \sum_{r} P_{\text {lab }}(r)
$$

こうして得られた $p(r)$ を用いて, 空間周波数領域におけ るエントロピーH'を次式(4) で定義することができる.

$$
H^{\prime}=-\sum_{r} p(r) \cdot \log p(r)
$$

ここで $H^{\prime}$ の最大值は, スペクトルがすべての周波数 $r に$ 対して均等に分布している（white noise の）ときに与
えられ，その值は $\log K(K$ は $r$ のとり得る值の個数であ り,ここでは $K=362 ）$ となる. そこで次式(5)により, 相対エントロピーHを求め, これを特徴量として用いる.

$$
H=H^{\cdot} / \log K
$$

この相対エントロピーHは 0 から 1 の範囲の值をとり, 画像のパワースペクトルが様々な周波数に分散している ほどその值は大きく（1 に近く）なり, 逆に特定の周波 数に集中しているほどその值は小さく $(0$ に近く $)$ なる. したがって, 壁紙画像に含まれる色や明るさの変化が非 周期的でランダムであるほど大きい值となる.

各サンプルについて計算された, これら 4 種類の特徵 量の值は表 1 に示されたとおりである.

\section{3 快適性の主観的評価と画像特徽量の関係}

まず, 前項で述べた 4 種類の画像特徵量と快適性の主 観的評価値との単相関を調べた. 図 $2 \sim 5$ はそれらの関 係を散布図として描いたものであり, 各図中の $R$ の值が 相関係数を示している.

平均明度之快適性は強い正の相関（相関係数 $0.737 ）$ を示し, 一方, 平均彩度と快適性は強い負の相関（相関 俰数 -0.714）を示していることが分かる. すなわち, 壁紙の平均的な色特性として, 高明度, 低彩度であるも のが視覚的に快適であると評価されていることになる. 平均周波数とエントロピーに関しては, 視覚的快適性と の単相関はあまり見られない.しいていえば平均周波数 がわずかに負の相関（相関係数 $-0.318 ）$ を示している 程度である. 前項で述べたように, 平均周波数の值は画 像におけるパターンの粗密の程度を表すと考えられるの で, この結果は壁紙がもつ主要な（特徽的な）柄が細か いほど, 快適性がやや低下する傾向にあることを示唆し ているが，それほど単純な関係ではないと予想される。

次に, これらの画像特徵量を説明変数に用い, 壁紙の 視覚的快適性を予測するための重回帰式について検討し た. 画像特徵量は 4 種類であるが, そのうち平均周波数 とエントロピーに関しては, 前報 [20]の結果などから, 非線形の相関も予想されたため, 各々の 2 次項を説明変 数に加え, 合計 6 変数とした. SPSS による重回帰分析の 結果を表 3 に示す. 説明変数によって単位やスケールが 異なるので, ここでは標準偏回帰係数の值から, 各変数 の寄与について考察する. まず, 単相関の結果からも推 測される通り, 平均明度は正の寄与, 平均彩度は負の寄 与を示している. 一方, 平均周波数とエントロピーにつ いては, 単相関では上記 2 変数の影響に隠れてあまり関 連が見出せなかったが, ここでは, ともに 2 次項が負の 倸数を示しており, 上に凸の 2 次的な関連があることが 分かった.つまり平均周波数とエントロピーは大きすぎ ても小さすぎても快適性を低下させることになる，もち 


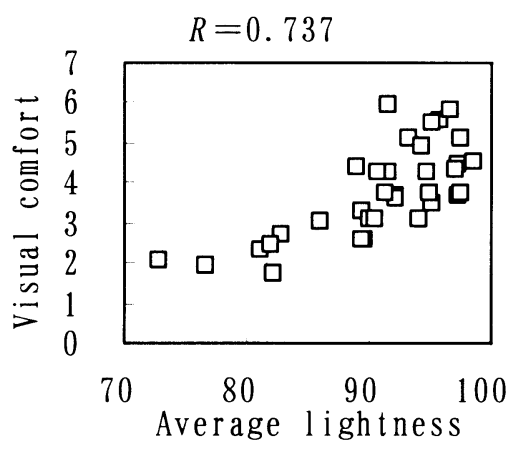

Fig. 2 Relationship between average lightness and visual comfort.

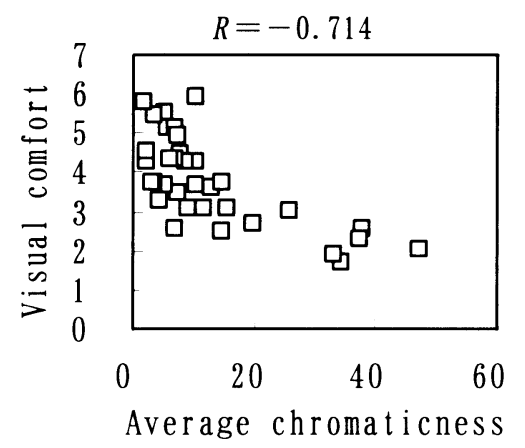

Fig. 3 Relationship between average chromaticness and visual comfort.

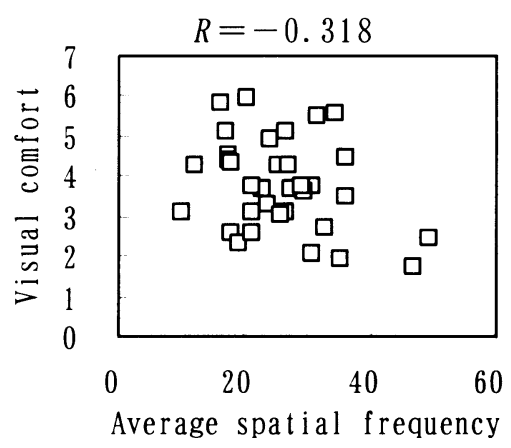

Fig. 4 Relationship between average spatial frequency and visual comfort.

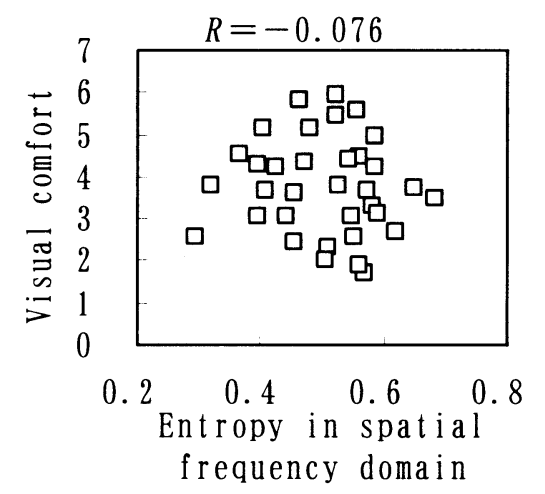

Fig. 5 Relationship between entropy in spatial frequency domain and visual comfort.

Table 3 Result of multiple regression analys is (34 samples).

\begin{tabular}{|l|c|c|c|c|}
\hline \multicolumn{1}{|c|}{ Explanatory variable } & regression coefficient & $\begin{array}{c}\text { regression coefficient } \\
\text { (normalized) }\end{array}$ & $\mathrm{t}$ value & P value \\
\hline Constant & -11.068 & & -1.696 & 0.101 \\
\hline Average lightness & 0.091 & 0.497 & 1.956 & 0.061 \\
\hline Average chromaticness & -0.027 & -0.277 & -1.126 & 0.270 \\
\hline Average frequency & 0.084 & 0.648 & 1.058 & 0.300 \\
\hline Square of average frequency & -0.002 & -0.692 & -1.148 & 0.261 \\
\hline Entropy & 26.351 & 2.102 & 1.902 & 0.068 \\
\hline Square of entropy & -28.146 & -2.192 & -2.004 & 0.055 \\
\hline
\end{tabular}

Table 4 Result of multiple regression analysis (17 samples with odd number).

\begin{tabular}{|l|c|c|c|c|}
\hline \multicolumn{1}{|c|}{ Explanatory variable } & regression coefficient & $\begin{array}{c}\text { regression coefficient } \\
\text { (normalized) }\end{array}$ & $t$ value & P value \\
\hline Constant & -5.478 & & -0.453 & 0.660 \\
\hline Average lightness & 0.059 & 0.368 & 0.716 & 0.490 \\
\hline Average chromaticness & -0.033 & -0.415 & -0.856 & 0.412 \\
\hline Average frequency & 0.095 & 0.828 & 0.576 & 0.577 \\
\hline Square of average frequency & -0.002 & -0.926 & -0.639 & 0.537 \\
\hline Entropy & 14.897 & 1.216 & 0.675 & 0.515 \\
\hline Square of entropy & -17.327 & -1.406 & -0.800 & 0.442 \\
\hline
\end{tabular}


ろん，表の最右欄に示されているように偏回帰係数の検 定における有意確率が十分に小さいとはいえないので断 定はできないが, 要するに適度な平均周波数とエントロ ピーをもった壁紙が視覚的快適性をもたらすものと考元 られる．前項で述べたように，エントロピーの值は画像 のパワースペクトルが様々な周波数に分散しているほど 大きくなり，逆に特定の周波数に集中しているほど小さ くなる．つまり，画像に含まれる色や明るさの変化が非 周期的でランダムであるほど大きくなる.したがって, 平均周波数とエントロピーの寄与をもう少し簡単に表現 するならば，「適度な粗さ（細かさ）と適度な周期性（非 周期性）をもつ壁紙が視覚的快適性をもたらす」となる.

図 6 は，横軸に視覚的快適性の主観的評価值（実測值） を，縦軸に重回帰式による計算值（予測値）をそれぞれ とり，34 サンプルの值をプロットしたものである．これ らの相関係数（つまり重相関係数）は 0.806 であり，上 記 4 種類の特徵量（うち 2 種類は 2 次項も含み, 6 変数） によってある程度快適性の予測が可能と考えられる.

さらに本手法の汎用性を確認するために， 34 サンプル のうち半数（具体的には奇数番）の 17 サンプルについて のデー夕を使って, 同じように重回帰分析を行い(表 4), その結果を用いて残り (つまり偶数番) の 17 サンプルの 快適性を予測してみた．図 7 はその值を図 6 と同じよう に実測值と比較して示したものである．この場合でも実 測值と予測值との相関は 0.802 となっており, 予測精度 の減少はほとんど見られない。また表 4 にあるように,

(サンプル数が少なくなったため, 有意確率の值がかな り大きくなってはいるが）標準偏回帰係数の值は前出の 表 3 のそれとほほ類似の傾向を示している. したがって 本手法はある程度の汎用性をもつものと考えられ，今回 用いたサンプルとは別の壁紙の評価に対しても有効であ ることが期待できる.

\section{4. 結简}

室内用壁紙の色柄による視覚的快適性について，被験 者による主観的評価と，画像解析によって得られる客観 的特徵量との関連を検討した. 使われている色の効果に おいては, 平均明度が高く, 平均彩度が低い（いわゆる 淡色系の）壁紙が快適であることが明らかとなったまま た，柄（すなわち空間的な色変化の特徵）による効果に おいては, 適度の平均周波数とエントロピーをもつ壁紙 が快適性をもたらすことも示唆された。

ただし，本研究で用いた壁紙画像は抽象柄のものがほ とんどであり，はっきりした具象柄を含むような場合に 対する評価法については，今後さらに検討する必要があ る. また本結果はディジタル画像として CRT 上に表示さ れた壁紙に対する印象評価によるものであり，はじめに 述べたように素材による質感の違いや，あるいは実際に
室内に施された場合の印象の違い（面積や観察時間の効 果）など，現実の場面へ適用するにはまだまだ考えねば ならない問題は多いかもしれないが，ある程度有効な示 唆が得られたと考えている.

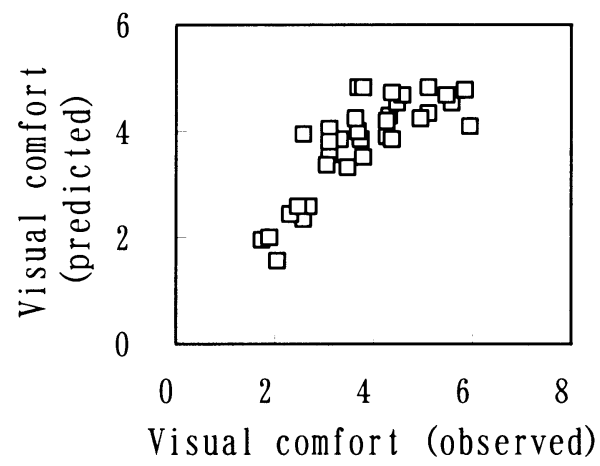

Fig. 6 Relationship between observed and predicted visual comfort (34 samples).

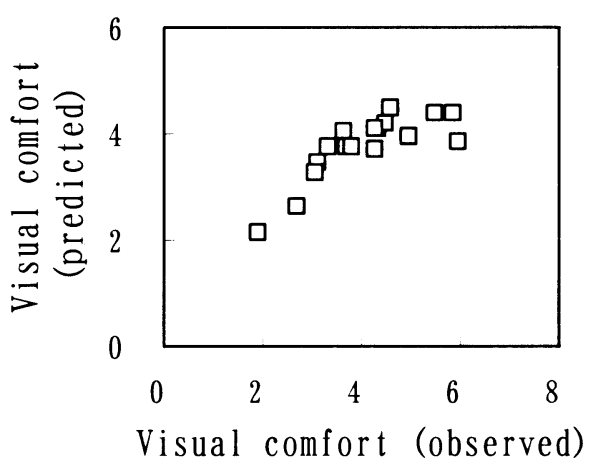

Fig. 7 Relationship between observed and predicted visual comfort (17 samples with even number). The predicted values were obtained by using regression coefficients for the other 17 samples with odd number.

\section{References}

[1] Nakamura, T. et al ; Sen' i Gakkaishi, 52, 27 (1996)

[2] Sato, T. et al ; Sen' i Gakkaishi, 53, 7 (1997)

[3] Sato, T. et al ; Sen' i Gakkaishi, 53, 131 (1997)

[4] Nayatani, Y. et al ; Bull. Electrotech. Lab., 29, 631 (1965)

[5] Mori, N. et al ; Bull. Electrotech. Lab., 29, 914 (1965)

[6] Mori, N. et al ; Bull. Electrotech. Lab., 30, 161 (1966)

[7] Mori, N. et al ; Bull. Electrotech. Lab., 30, 741 (1966)

[8] Mori, N. et al ; Bull. Electrotech. Lab., 30, 889 (1966)

[9] Nayatani, Y. et al ; Bull. Electrotech. Lab., 31, 1153 (1967)

[10] Asano, C. et al ; Bull. Electrotech. Lab., 32, 195 (1968)

[11] Nayatani, Y. et al ; Bull. Electrotech. Lab., 32, 221 (1968)

[12] Kato, Y. et al ; J. Jpn. Res. Assn. Text. End-Uses, 25, 167 (1984) 
[13] Kosuge, K. et al ; J. Jpn. Res. Assn. Text. End-Uses, 31, 38 (1990)

[14] Yoshioka, T. ; J. Jpn. Res. Assn. Text. End-Uses, 31, 250 (1990)

[15] Ishii, M. et al ; Graphics and CAD, 70, 37 (1994)

[16] Ishii, M. et al ; J. Jpn. Res. Assn. Text. End-Uses, 37, 646 (1996)

[17] Kosuge, K. et al ; J. Jpn. Res. Assn. Text. End-Uses, 31, 427 (1990)

[18] Yanagida, K. et al ; J. Text. Mach. Soc. Japan, 49, 222 (1996)
[19] Ishii, M. ; J. Jpn. Res. Assn. Text. End-Uses, 41, 535 (2000)

[20] Kawamoto, N. ; Sen' i Gakkaishi, 58, 387 (2002)

[21] Sagawa, K. ; Col. Res. Appl., 24, 313 (1999)

[22] Watanabe, A. ; Television, 20, 730 (1966)

[23] Sakata, H. et al ; Television, 31, 29 (1977)

[24] G.J.C.van der Horst et al ; J.Opt.Soc.Am., 59, 1482 (1969)

[25] E.M.Granger et al ; J.Opt.Soc.Am., 63, 1173 (1973)

[26] K.T.Mullen, J.Physiol., 359, 381 (1985) 